\title{
Environmental impact on the toxicologically relevant arsenic species in ground water of 2 nd aquifer of coal mining area and release in a reservoir: Risk assessment to aquatic life
}

\author{
Asif Unar \\ University of Sindh \\ Tasneem Kazi ( $\square$ tgkazi096@gmail.com ) \\ University of Sindh https://orcid.org/0000-0003-3683-8959 \\ Shahabuddin Memon \\ University of Sindh
}

\section{Research Article}

Keywords: Coal Aquifer, arsenic species, reservoir, fish, estimated daily intake

Posted Date: May 28th, 2021

DOI: https://doi.org/10.21203/rs.3.rs-562195/v1

License: (c) (i) This work is licensed under a Creative Commons Attribution 4.0 International License. Read Full License 


\section{Abstract}

In present study, the variation in the concentrations of inorganic As species (penta and trivalent) in ground water of coal mining area (2nd aquifer) and its drain outlet/discharge in a reservoir/gorano dam. The water samples were collected from reservoir at four different sites (RW1, RW2, RW3 and RW4. At site four of reservoir (RW4) the fish farming is also carried out, from where a fish species Tilapia (Oreochromis mossambicus) was also collected. The solid phase extraction using titanium dioxide as an adsorbent was applied for the determination of inorganic As. The arsenite (AsIII) was found by an advance extraction method (cloud point extraction) by means of a hydrophobic chelating reagent and the obtained hydrophobic complex was deceived in a surfactant (Triton X-114). Physico-chemical, parameters of all water samples collected from ground water of aquifer 2 of coal mining area (AQ2), drain/discharge outlet (DW) and four sites of reservoir/Gorano dam were carried out. The resulted data indicated that physicochemical parameters (conductivity, total dissolved salt, $\mathrm{pH}$ ) of all collected samples were surpassed the WHO recommended values for drinking water excluding $\mathrm{pH}$. The different organs (gills, scale, liver and muscles) of 0 . mossambicus were analyzed for total As. The resulted data designated that accretion of As in various tissues of selected fish species was found in decreasing order as liver $>$ gill $>$ muscles $>$ scale. The bioaccumulation factor was calculated $>28$. To evaluate the exposure of As via consuming the fish muscles by people was calculated by daily intake of As (EDI), and found to be significantly higher than the allowable limit $(2.1 \mu \mathrm{g} / \mathrm{Kg} /$ day $)$ by food organizations.

\section{Highlights}

- Change in the ratio of penta and trivalent As species according to environmental impact

- The resulted data indicated that physicochemical parameters of water samples of coal mining area were $>$ WHO values

- The elevated levels of both As species and $\mathrm{F}^{-}$designated the lithological outcome on ground water

- The EDI of As via muscles of fish was calculated from 3.3 to $5.0 \mu \mathrm{g} / \mathrm{kg}$ body weight/day > EDI by FAO/WHO

\section{Introduction}

Nowadays numbers of agencies (national and international) are operational on diverse power generating schemes around the Thar coalfield in district Tharparkar, Sindh, Pakistan (J Ali et al. 2015; Imran et al. 2014). Coal restrains more than 80 elements, amongst which > 20 trace elements are harmful (Swaine, 2000). The harmful metals and metalloids can be liberated into the environment through the procedures of mining, transferring, and usage (Finkelman et al., 2002), and thus polluting the surroundings. The different kinds of pollutants created during mining are basically minerals in the rocks, which are solublised in water, come up to in contact (Singh et al. 2012 ; Ali et al., 2015), and thereby adversely distressing its quality and utility. However, water can dissolve lots of matters from rock and soil. The refuse masses includes sulphides (pyrite) be able to creates acid mine drainage crisis in the environment. The removal of huge amount of water from various depth/aquifer through mining processes frequently causes changes in its physicochemical properties and in addition to creates depression of groundwater in the area which can creates scarceness (Singh et al., 2012; Tripathy, 2010).

Arsenic (As) in the water is a severe expected disaster for living and non-livings, which initiate from different natural scheme, such as geological resource (Anawar et al., 2003; Singh 2010; Smedley et al., 2002). Arsenic is not only affects to skin of healthy livings but also different diseases such as keratosis, black foot disease, hyper-and hypo pigmentation, diabetes and cardiovascular disorders (Abernathy et al., 2003; Milton et al., 2004). The arsenic compounds inorganic in nature grouped as major carcinogens, it created adverse impact on the human health to causes cancers of the lungs, skin, and bladder (Morales et al., 2000; Yoshida et al., 2004). The elevated intake/exposure of As creates different undesirable effects on the living beings, however the literature reported information recommend that the As compounds inorganic in 
nature demonstrate the maximum toxic intensity, whereas the organic compounds of As are generally have lower toxic impact (Duker et al. 2005). Amongst all forms of As, it's trivalent form appears to have more severely created toxic effects on living beings

Generally the main transportation of toxic metals and metalloid (As), naturally occurs by water. It was reported in literature (Hughes et al. 2011), that most common forms of inorganic species are arsenate and arsenite in varying ratios. The ratio of arsenite to arsenate (AsIlI : AsV) is not just reliant on the type/source of water (ground/surface) although the redox conditions are also important. The evaluation of adverse environmental and biological impacts of As, generally based on its speciation. Furthermore, it is required to propose/develop susceptible and specific methodologies to categorize and measure the As species inorganic forms in water of different origin. For that purposes different advance extraction methodologies (separation/ pre-concentration) are reported in literature (Murata et al., 2005; Baig et al.2009; Ali et al., 2015)).

To analyzed the inorganic As (total levels), a solid phase extraction method consist of adsorbed on a solid phase (sorbent) from liquid phase (generally water/aqueous sample solution) is used (Zhang et al., 2005, 2007; Brahman et al., 2013). To determined and separate the $A s^{I I I}$ and $A s^{V}$, a cloud point extraction method (CPE), which is based on the phase separation of non-ionic surfactants from aqueous solution or water (Liang et al. 2009). These pre-enrichment methods are easy, low charges, high pre-concentration factor to determined trace quantities of As species and environmental friendly.

The aquatic organism especially fish can generally be used for long time as prominent specimen for biomonitoring the pollution of aquatic environmental as well as excellent markers of toxicity of toxic metals and metalloids in ecosystem (Tisler and Zagorc- Koncan 2002; Das et al. 2012). Different species of fish, are important aquatic organisms, if livelihood in polluted water can be incorporate the toxic trace elements by means of their food chains; they assimilate the metals by intake of particulate matter suspended in water, ion exchange of soluble metals across lipophilic membranes, as the gills, adsorption on tissue and membranes surfaces (Alam et al., 2002). The bioaccumulation of metals is consequently, an indicator of the pollution grade of the relevant water body (Moiseenko and udryavtseva, 2001).

The biotransformation of As from water to fish come into view to involve diverse systems/mechanisms to convert it in less toxic forms, and afterward readily excreted (Kumari et al. 2006). The elevated concentrations of As in an ecosystem, higher than permissible limit, $>10 \mu \mathrm{g} / \mathrm{L}$, and consuming As-contaminated fish had adverse impacts on various physiological systems such as growth, reproduction, immune function, gene expression, enzyme activities, ion regulation, and histopathology of fish (Datta et al. 2009; Pedlar et al. 2002a, b). The consumption of fish (As-contaminated) might be affects the humans and created unfavorable health effects (Kar et al. 2011).

On the base of these information, the present work has been carried out to explore the difference in physicochemical characters and speciation inorganic As, in the groundwater of 2nd aquifer of block 2 of Thar coal mining area, where power generation project is going on, detail is reported elsewhere (Ali et al.,2015). The arsenic as inorganic As (total) and it's both species (As ${ }^{I I I}$ and $A s^{\vee}$ ) were find out by diverse advance extraction methodologies, cloud point and solid phase extractions, respectively as given in our preceding works (Brahman et.,al.2014; 2016, Baig et.al.2009). The mutual relationships of As species with different physicochemical parameters of water samples obtained from AQ2 (groundwater), DW (drain outlet) and from four sites of reservoir were estimated. The accuracy of mythologies which are used in present study was valid by standard addition method and that's reported in our previously works. The total arsenic was determined in different tissues of fish by ICP EOS, formerly acid oxidation of matrix by microwave oven. The daily intake of As was estimated via consuming fish (muscle tissues) for potential risks to human health.

\section{Material And Methods}




\subsection{Study area}

The water sampling was carried from a newly developed reservoir (Gorano dam) for collecting ground water of 2nd aquifer of block II of Thar coal mining area, which is near Taluka, Islamkot District Tharparkar, and Sindh, Pakistan. This is geographically located at southern in Pakistan at $24.5321880 \mathrm{~N}, 70.3751350$ E. which is $27 \mathrm{~km}$ away from coal mining area. The further detail was reported in previous work (Ali J et al., 2015).

\subsection{Chemical reagents and glassware}

Ultrapure water which was used throughout the procedural system was taken from ELGA lab water system (Bucks, UK). All chemicals and regent preparation were made according to standard methods used for the determination of total and arsenic species by advance extraction methodologies as reported earlier (Brahman et al., 2013). The reagents non-ionic surfactant, Ammonium pyrrolidine dithiocarbamate and adsorbent (titanium dioxide) obtained from Merck (Darmstadt, Germany), Sigma Aldrich (Germany) and Fluka (Buchs, Switzerland). For accuracy of methodologies matrices matched certified refrence materials (SRM 1643e and DORM-2) obtained from National Institute of Standards and Technology (Gaithersburg, MD, USA).

\subsection{Instrumentation}

The instruments were used during this study are given followings (WIROWKA Laboratoryjna type WE-1, nr-6933 centrifuge speed range 0-3,500 rpm, timer 0-60 min, 220/ $50 \mathrm{~Hz}$ (Mechanika Phecyzyjna, Poland), was used for centrifugation. The $\mathrm{pH}$ meter (720-pH meter, Metrohm) was used for measurement of $\mathrm{pH}$ of samples. ICP-OES (Inductively coupled plasma optical emission spectroscopy) and atomic absorption spectroscopy with flame and graphite furnace were used for iron and arsenic determination. For the physic-chemical parameters such as, Electrical conductivity (EC), and Total dissolved solids (TDS) a InoLab conductometer (720,Germany) was used.

\subsection{Sampling and pretreatment}

Samples of water were collected in May to June, 2019. The first batch of ground water was sampled directly from second aquifer at the depth of 100-120 m with the legal permission and assistance of Sindh coal authority. The high power compressor was operated for withdrawing ground water (GW) of second aquifer during construction of power plant. The second sampling point was from drain outlet (ground water of 2 nd aquifer discharge). Then again sampling of water were carried out from four more sites at equal distance of $500 \mathrm{~m}$ (length of dam/reservoir is $2.0 \mathrm{~km}$ ). The cleaned polyethylene plastic bottles with stoppers were used for storing the water samples (Arain et al., 2009; Brahman et al., 2013). The water samples of all origins were kept in an ice box and transported to the working laboratory on the similar day. About twenty water samples were collected from each origins. In laboratory ten composite sample of each GW, drain water (DW), and four more sites termed as SW1, SW2, SW3, SW4 were made and filtered through 0.45-mm filter paper with the help of vacuum pump. (Kazi et al. 2009; Brahman et al., 2013). The determinations of inorganic As (iAs) and arsenate (AsIII) were carried out on the similar day to reduce the danger of alteration of species as reported elsewhere (Gong et al. 2002; Braman et al., 2013).

At site 4 of the reservoir the authority made a fish farm separated from site 3 by a net. The different tissues of 0 . mossambicus (omnivorous), were sampled during two month, caught with a nets system and packed in polyethylene bags, and kept in a ice box $(n=20)$. According to authority the fish farming is start on April 2019. The samples of fish ( $n=$ 20), collected at size of (15-20 cm) with weight ranges (500 - $750 \mathrm{~g})$. In laboratory made 10 composite samples. The all fish samples were dissected to separated different parts (scales, gills and muscles), and kept separately at $-4 \mathrm{C}$ till further experimental work. Triplicate of each organ of fish samples were dried at $100^{\circ} \mathrm{C}$ to determine the moisture content. The percentages of moisture in fish muscle tissues were found to be $74.0 \pm 2.5 \%$.

\subsection{Procedure}


During analysis of water initially $50 \mathrm{~mL}$ of each water samples were taken in $100 \mathrm{~mL}$ beakers and then with the help of $\mathrm{pH}$ meter and conductometer physico-chemical parameters such as $\mathrm{pH}$, TDS, EC and salinity were measured respectively. The TDS were not measured in initial water samples due to high values, then samples were 10 times diluted and conductometer was able to measure TDS.

\subsection{Estimation of total As}

The total arsenic (tAs) in the groundwater of aquifer of coal mining block-2 and drain outlets in a reservoir, water samples were collected from surface and bottom layers from four sampling sites (RW1, RW2, RW3 and RW4) were determined by ICP-OES. For accuracy, a certified reference sample of water (SRM 1643e) was analysed simultaneously

\subsection{Estimation of total and inorganic arsenic species}

The concentration of the total iAs and its trivalent $\left(A s^{I I I}\right)$ and pentavalent ( $A s^{V}$ ) species were evaluated by two advance extraction/enrichment methodologies (solid phase and cloud point extractions), respectively. The detail procedures and effects of variable are reported in previously reported work (Maity et al., 2004; Baig et al., 2009; 2010; Brahman et al., $2013 ; 2014)$. As the levels of $\mathrm{As}^{\mathrm{V}}$ can not be found by the proposed analytical methods as mentioned above. However its concentrations were determined by the variation among the total iAs and As'II.

\subsection{Acid digestion of Fish tissues}

The matrices of selected tissue of fish species and certified reference material (DORM-2) were oxidized by mixture of acid $\left(\mathrm{HNO}_{3}\right.$ and $\left.\mathrm{H}_{2} \mathrm{O}_{2}\right)$ using microwave as reported in our previous work (Shah et al., 2009). The clear digestion solution of all tissues were diluted with dilute $\mathrm{HCl}$ and kept separately in PTFE flasks. Then subject to ICP-OES for determination of total As. The methodology for evaluation of total As in different tissues of fish was promised by the analysis of certified reference material DORM-2 (dogfish muscles), triplicate analysis of each real samples as well as reagent blank. The resulted data indicates in agreement with the certified values of CRM (Table 1). The calculated t-value was compared with the theoretical value. Results were considered significant at $\mathrm{P}<0.05$.

\subsection{Analytical figure of merit}

The calibration graph for AsIII and tAs was prepared in the range of 2.0 to $10 \mu \mathrm{g} / \mathrm{L}$ to obtain linear with a correlation coefficient of 0.996 and 0.995 , respectively. The limit of detection (LOD) of Asll and tAs, values were $0.05 \mathrm{and} 0.22 \mu \mathrm{g} / \mathrm{L}$. For validation of speciation of As, certified reference material are not accessible, then added As ${ }^{I I I}$ and iAs at three concentrations levels in replicate subsamples of RW4, then applied both proposed methods. The improvement of both analytes for AsIII and iAs were generally > 98\% (Table 2). To validate the methodology for tAs, the matrix matched certified reference materials of water (SRM 1643e) and muscles of dog fish (DORM 2) were evaluated. The standard recovery was observed above than $98 \%$, whereas the $\%$ coefficient of variation was $<5 \%$ (Table 2 ).

\section{Results And Discussion}

Concentrations of the total iAs and its species (AsIII and AsV) in water samples obtained from AQ2, DW and four sites of reservoir water samples were estimated by enrich methods (SPE and CPE), respectively. The details of effects of different variables of both methodologies are indicated in our previous work (Baig et al., 2010b; Brahman et al., 2013; 2014). The results of physicochemical parameters of groundwater samples (AQ2), drain out let and four sites of reservoir (Gorano dam) are given in Table 2. The resulted data mentioned as mean values with standard deviation $(n=30)$ of each physicchemical parameters, are shown in Table 3. To estimate the correlations using Pearson correlation coefficients ( $r$ ) among the data of variables, were estimated. The obtained resulted values of different characteristics of all collected water samples of different origin, water samples of aquifer 2 (GW), drain outlet (DW) and from different four sites of reservoir (RW1, RW2, RW3 and RW4) were extensively deviate from the allowable values by WHO, for water uses for drinking and cooking purposes. The pH of AQ2, DW, RW1, RW2, RW3 and RW4 was found in the range of 7.64 - 8.7, 7.5-8.2, 7.4-7.85, 
7.3-7.8, 7.1-7.6 and 6.8-7.4 respectively, the $\mathrm{pH}$ of water samples of all origins are consisted with WHO regulated levels, however it is slightly alkaline in nature. This is attributable to the $\mathrm{HCO}_{3}{ }^{-}$ion concentration, which is relatively high in all sites including GW < DW and all sites of reservoir, ranged as 238 to $450 \mathrm{mg} / \mathrm{L}$. However, the $\mathrm{pH}$ values of water samples of reservoir were diminished with the distance. This reducing in $\mathrm{pH}$ is taking placed owing to the decline in dissolved minerals (Tripathy et al., 2010).

The mean values with standard deviation of TDS and EC of water samples of different origin, AQ2, DW, RW1, RW2, RW3 and RW4. The TDS values in AQ2, DW, RW1, RW2, RW3 and RW4 were found in the range of $8900-9650,8240-9340$, $8180-9200,6900-7820,5840-6770$ and $4920-5810 \mathrm{mg} / \mathrm{L}$, respectively, and the EC were found in the range of $9.5-$ $11.5,9.2-10.8,8.82-10.8,7.82-9.54,7.25-8.3,6.1-7.45 \mathrm{mS} / \mathrm{cm}$, respectively. The total dissolved and electrical conductivity enhanced $\geq$ five times than WHO suggested allowable limit for water samples used for drinking/domestic purposes, which may be owing to the elevated salt and mineral substances in the selected aquifer-2 of coal mining area (Block 2), drain water at initial and different distance of reservoir (RW1, RW2, RW3 and RW4 corresponding to (average $500 \mathrm{~m}$ among each site).

It was observed that the EC of initial drained water (DW) have higher values than four sites, decreasing (>38.0\% from DW to S4). The total dissolved salts at S4 were about $44 \%$ reduced than initial values of DW. The EC of water samples obtained from AQ2 was originating to be 24 to 40 time elevated as recommended by WHO. It was observed that the changes in the EC values are relevant to TDS assessment. It was detected that the groundwater samples (AQ2) and DW have elevated concentrations of TDS which might be indicates that either due to the solubilization of lithogenic salts in ground water of coal mining area (block 2). The levels of Fe were observed in the range of $1.35-1.7,1.18-1.6,0.88-1.3$, 0.65-1.0, $0.47-0.68$ and $0.42-0.52 \mathrm{mg} / \mathrm{l}$. The levels of Fe was 4 to 6 folds higher in water samples of AQ2, whereas in sample $\mathrm{S} 4$ the concentration of it was reduced but still higher than recommended levels of it by WHO $(0.3 \mathrm{mg} / \mathrm{L})$. The value of $F$ - were observed in the range of $(32.4$ - 48.6, 30-45.2, 27.5-41.2, 25.6-38.4, 22.8-34.6, 18.5-28.8) mg/l, respectively in AQ2, DW, RW1, RW2, RW3 and RW4 The levels of HCO3 - were found in the range of 411-494, 399-483, 300-480, 271-434, 246-362 and 228-301 mg/l in AQ2, DW, RW1, RW 2, RW3 and RW4, respectively (Table 2).

The resulted values of toxic element (tAs) in groundwater of second aquifer of Thar coal mining area, its drain outlet and four sampling sites of reservoir have high concentration. The obtained results indicated that ground water (AQ2), DW, RW1, RW2, RW3 and RW4 were contaminated with higher concentration of As, than the suggested WHO limit for drinking water $\left(10 \mu \mathrm{gL}^{-1}\right)$. The total levels of As in AQ2 was found in the range of $37.4-54.5 \mu \mathrm{gL}^{-1}$, whereas the drain water (discharge outlet) have As concentration slightly lower than AQ2 (35.7-53.3 $\mathrm{gL}^{-1}$ ) however the differentiation was not significant $(p<0.05)$. The concentration of As in water samples of reservoir at different sites/distance from drain outlet to RW4, were found to be decreasing, observed in the range of 34.5-47, 30.0- 46.5, 26.4-42.4 and 22.6-37.4 $\mu \mathrm{gL}^{-1} \mathrm{~L}$. It was observed that $>40 \%$ of As was reduced at RW4, indicated that the salts of As was settled down. these data are consisted with literature reported study on geochemical occurrence of arsenic (Anwar et al., 2003).

The concentration of iAs was found to be 2 to $5 \%$ lesser than the total As in all 6 sites, demonstrating the less availability of As organic in nature, in all selected water samples (Thirunavukkarasu et al., 2002). To determined the inorganic As (iAs) in water samples obtained from AQ2, drain outlet and reservoirs using titanium dioxide as solid adsorbent, which has large surface area, whereas the inorganic specie (trivalent As ) determined be an simple, rapid, sensitive, inexpensive advance extraction method (Cloud point extraction), the detailed discussion about the optimizations of different factors of both methods are given in our previous work (Baig et al., 2009; Brahman et al., 2013; Ali et al.,2015). The information about the levels of As in surface/ground water samples, speciation of inorganic arsenic, especially trivalent and pentavalent As is essential, might be owing to their physiological and toxicological roles. Thus, it is most crucial to find out its species rather than the total amount in water samples of different origin. 
The concentration of $\mathrm{As}^{\mathrm{V}}$ in AQ2, DW, RW1, RW2, RW3 and RW4 were observed in the range of 27.0 - 34.46, 26.9-33.66, 19.6-25.5, 11.0-21.2,7.6-15.4 and 5.8-12.8 $\mu \mathrm{g} / \mathrm{L}$, while As3 levels was enhanced consequently from 12.7 - 18.4, 12-17.6, $13.4-19.3,17.6-24.2,18.0-25.8$ and $18.6-28.4 \mu \mathrm{g} / \mathrm{L}$, respectively. The resulted data indicated that the mean ratio of As ${ }^{V}$ and As ${ }^{\text {III }}$ in ground water samples of Aq2 and drain outlet was observed about 2:1, whereas at site RW4 the ratio become reverse about $1: \leq 3$, respectively. The increasing levels of $A s^{\text {III }}$ observed from RW2 as compared to $A s^{\mathrm{V}}$, which may be owing to its lesser amount of oxidizing atmosphere, described by lower concentrations of $\mathrm{HCO}_{3}{ }^{-}(\geq 230 \mathrm{mg} / \mathrm{L}) \mathrm{with} \mathrm{pH}$ values of $\geq 7.1$ (Maity et al., 2004). However this type of practices are believed to be accountable for the liberate of As in oxidizing quaternary sedimentary aquifers (Singh, 2006; Smedley et al., 2002). The pyretic material or black shale occurring in the underlying geological strata is the main resource of iAs (Thornton and Farago et al., 1997). The organic matrices, redox potential, and $\mathrm{pH}$ are responsible for instability of As species in natural waters for the reason to the conversion among As ${ }^{\mathrm{III}}$ and $\mathrm{As}^{\mathrm{V}}$ (Thirunavukkarasu et al.2002; Wang and Mulligan 2006; Baig et al. 2009; Chen et al. 2009).

It was monitored that in water samples of $A Q 2$, the levels of $A s^{\vee}$ was high up as compared to $A s^{\prime \prime I}$. It was indicated in literature that ground water of coal mining area (AQ2) contains high levels of $\mathrm{As}^{\mathrm{V}}$ might be due to oxidizing environment, which is also confirmed on the basis of high levels of $\mathrm{HCO} 3(>400 \mathrm{mg} / \mathrm{L})$. The elevated levels of both As species, $\mathrm{F}^{-}$, TDS, EC in GW and DW designated the lithological outcome on water samples of reservoir. It was observed that the correlation coefficient among $\mathrm{F}^{-}$and $\mathrm{pH}$ is positive $(\mathrm{r}=0.786)$; which is same as indicated in previous work (Vasquez et al. 2006). The positive correlation among $\mathrm{F}^{-}$and $\mathrm{OH}^{-}$may be owing to the alike ionic radii, which frequently replace each other (Rafique et al. 2009). It was indicated in a study that oxidation is change the soluble $A s^{\prime \prime \prime}$ to $A s^{\mathrm{V}}$, which is resulted into precipitation of penta-valent As. This is necessary for anoxic groundwater, since As ${ }^{\text {III }}$ is the common form at close to neutral pH (Masscheleyn et al., 1991). Geology and groundwater environment make one form, either or dominant (Andersen 1991). Although it is thermodynamically supported in oxic and in anoxic water samples, whereas it was also studied that the both species of As can coexist in waters (Haque and Johannesson, 2006).

\section{Arsenic determination in fish samples}

The mean values of As in different tissues with standard deviation are mention in Table3. The total As in the selected tissues of O.mossambicus was in the order: liver > gills > muscles >scale. It was observed that the contents of As in the gill and liver are elevated than its contents in muscle, The observed data are dependable with reported work (Suhendrayatna, et al., 2001). The contents of total arsenic in muscles tissues of 0 . mossambicus was found in the range of 0.8 to 1.2 $\mu \mathrm{g} / \mathrm{g}$, whereas lower contents was The As concentrations in scale of selected fish was found to be lower than other tissues, found in the range of 0.45 to $0.51 \mu \mathrm{g} / \mathrm{g}$. The estimated average contents of As in the selected tissues of 0 . mossambicus are matched up in the studies work. The Has-Schon et al. (2006), determined As in fish species (five) obtained from River Neretva, Croatia, have As contents in gills (0.005-0.255) ; liver (0.005-0.227) and muscles (0.038$0.309) \mu \mathrm{g} / \mathrm{g}$. Delgado-Andrade et al.,2003 stated the concentrations of As in muscles tissues of fish samples ranged as $(0.396-12.58) \mu \mathrm{g} / \mathrm{g}$, obtained from south-east Spain. Rosemond et al.,2008 indicated that in muscles tissues, intestine and liver of five freshwater fish species contains As (0.58-1.14), (1.47-8.91), (0.42- 2.24) $\mathrm{gg} / \mathrm{g}$, respectively, collected from Back Bay near Yellow knife Canada. Jankong et al. (2007), analyzed freshwater fish from arsenic-contaminated and non-contaminated sites in Thailand for arsenic content in their edible muscle tissue $(0.051-0.806) \mu \mathrm{g} / \mathrm{g}$. Shah et al., reported the average contents of As in different tissues of 10 fish species and indicated that the broad distributions of As concentration in different tissues were found in the range of, gills (1.01-10.4), , liver (3.51-10.9), muscle (2.12-15.2) $\mu \mathrm{g} / \mathrm{g}$ on dried basis.

The concentration of As in different tissues of selected fish species were found to be elevated, as related the values of As in different tissues as reported in literature excluding the results reported by Rosemond, et al., (2008), and Delgado- 
Andrade et al. (2003). The cultured fish are distributed by the authority to poor community resided in the villages near by the gorano dam.

The estimated daily intake (EDI) per day for adults was estimated by equation cited in a previous report (Copat et al., 2012; Kai et al., 2016)

$(\mathrm{EDI}=\mathrm{C} \times \mathrm{IR}) / \mathrm{BW}$

where IR eating amount of muscle tissues of fish, $C$ is the concentration of As $(\mu \mathrm{g} / \mathrm{g}$ ) and BW (body weight) It was estimated that a person (body weight $60 \mathrm{~kg}$ ) eating commonly $250 \mathrm{~g}$ of muscles of fishes per day, the intake of As was calculated in the ranges from 3.3 to $5.0 \mu \mathrm{g} / \mathrm{kg}$ body weight/day (Table 3), which are higher than the FAO/WHO tolerable daily intake of $2.1 \mu \mathrm{g} / \mathrm{kg} /$ day of As.

The bioaccumulation factor calculated as the ratio of the concentration of As in different tissues of fish and its concentration in water samples of ecosystem.

\section{$B A F=$ As in tissues of $\mathrm{fish} /$ As levels in water}

Therefore, further studies will be needed to acquire a better information of how particular factors, customary cooking procedure, constituents of foods as well as utilization of As contaminated water of reservoir (average value 32 to $47 \mu \mathrm{g} / \mathrm{l}$ ), particularly in selected area of Pakistan, can create adverse impact on health of local population. It was investigated immensely that ground water of Tharparkar (coal mining area) are contaminated with As causes considerable threats to the health of local communities, However there is no domestically treated water is supply in these areas and groundwater is still widely used due to the lack of other sources. The very common symptoms of arsenic exposure to children and adults such as skin disorders (black rain drops on face and arms) in addition to general weakness, anemia, and gastrointestinal problems are very common to local people of study area (Tharparkar) (Brahman et al., 2016).

\section{Conclusion}

It was observed that the release of groundwater of aquifer 2 of coal mining area due to development of an electric power plant, in a reservoir might be contaminating the ecosystem of reservoir. The physico-chemical characteristics, anion, cation, arsenic speciation (using advance extraction methods) were evaluated. The resulted data indicated that the physic-chemical variables were successively reduce from DW to RW4, the As concentrations was reduced $>35 \%$ of those values observed in water samples of ground water (AQ2). In GW and DW water sample dominate As specie is AsV, the mean ratio of AsV to AsIll was found as 2:1, whereas at RW4 the ratio of both species become reverse about 1: $\leq 3$. The bio-accumulation of As in a fish species 0 . mossambicus was monitored in the decreasing order: liver $>$ gills > muscles >scale. The As contents in the gill and liver are elevated than its concentration in muscle tissues. The estimated daily intake was calculated on the consumption of $250 \mathrm{~g}$ of fish muscles per person per day ranges from 3.3 $5.0 \mu \mathrm{g} / \mathrm{kg}$ body weight/day which are higher than the FAO/WHO tolerable daily intake of $2.1 \mu \mathrm{g} / \mathrm{kg} / \mathrm{day}$ of As.

\section{Declarations}

\section{Conflict of interests}

The all authors declared not any conflict of intrest

\section{Credit authorship contribution statement}


Tasneem Gul Kazi and Shahabuddin Memon: Made a project of this whole research work, composed the work, Asif Ali Unar: had done sampling and analyzed all physicochemical parameters

\section{Acknowledgment}

The authors would like to thank the National center of Excellence in Analytical Chemistry (NCEAC), University of Sindh, Jamshoro, for providing financial support and excellent research lab facilities for scholars to carry out the research work.

\section{References}

Abernathy, C.O., Thomasy, D.J., Calderon, R.L., 2003. Toxicity and risk assessment of trace elements. Health effects and risk assessment of arsenic. Am. Soc. Nutri. Sci. 133 (5), 1536S-1538S.

Alam M.G.M., A. Tanaka, G. Allinson, L.J.B. Laurenson, F. Stagnitti, E.T.A., 2002. Snow, Comparison of trace element concentrations in cultured and wild carp (Cyprinus carpio) of lake Kasumigaura, Jpn. Ecotoxicol. Environ. 53 (3), $348-$ 354.

Anawar, H.M., Akai, J., Komaki, K., Terao, H., Yoshioka, T., Ishizuka, T., Safiullah, S., Kato, K., 2003. Geochemical occurrence of arsenic in groundwater of Bangladesh sources and mobilization processes. Journal of Geochemical Exploration 77, (23) $109-131$.

Andersen L. C. D., Bruland, K. W. 1991 "Biogeochemistry of arsenic in naturalwaters: the importance ofmethylated species," Environmental Science and Technology, vol. 25, 3, pp. 420-427.

Arain M, Kazi T, BaigJ,JamaliM, AfridiH,Shah A,JalbaniN, SarfrazR (2009) Determination of arsenic levels in lake water, sediment, and foodstuff from selected area of Sindh, Pakistan: estimation of daily dietary intake. Food Chem Toxicol 47(1):242-248

Arain, M.B., T.G. Kazi *, M.K. Jamali, N. Jalbani, H.I. Afridi, A. Shah,2008 Total dissolved and bioavailable elements in water and sediment samples and their accumulation in Oreochromis mossambicus of polluted Manchar Lake.

Chemosphere 70 (10) 1845-1856

Baig JA, KaziTG, Arain MB, Shah AQ, Kandhro GA, Afridi HI, Khan S, Kolachi NF, Wadhwa SK (2011) Inorganic arsenic speciation in groundwater samples using electrothermal atomic spectrometry fol- lowing selective separation and cloud point extraction. Anal Sci 27(4): 439

Baig, J.A., Kazi, T.G., Shah, A.Q., Arain, M.B., Afridi, H.I., Kandhro, G.A., Khan, S., 2009b. Optimization of cloud point extraction and solid phase extraction methods for speciation of arsenic in natural water using multivariate technique. Analytica Chimica Acta 651(1), 57-63.

Baig, J.A., Kazi, T.G., Shah, A.Q., Kandhro, G.A., Afridi, H.I., Arain, M.B., Jamali, M.K., Jalbani, N., 2010. Speciation and evaluation of Arsenic in surface water and ground water samples: a multivariate case study. Ecotoxicology and Environmental Safety 73(5), 914-923.

Brahman, K D , Kazi, T G , Afridi, H I , Naseem, S , Arain, S S , Ullah, N , 2013. Evaluation of high levels of fluoride, arsenic species and other physicochemical parameters in underground water of two sub districts of Tharparkar, Pakistan: a multivariate study. Water Res. 47(3), 1005-1020.

Brahman, K D , Kazi, T G , Baig, J A , Afridi, H I , Khan, A , Arain, S S , Arain, M B , 2014 Fluoride and arsenic exposure through water and grain crops in Nagarparkar, Pakistan. Chemosphere 100, 182-189. 
Brahman, K.D., Kazi, T.G., Baig, J.A., Afridi, H.I, Arain, S.S; Talpur, F N Kazi, A G Ali, J Panhwar, A H Arain, M. B. (2016) Exposure of children to arsenic in drinking water in the Tharparkar region of Sindh, PakistanScience of the Total Environment 544 653-660.

Chen D, Huang C, He M, Hu B (2009) Separation and preconcentration of inorganic arsenic species in natural water samples with 3-(2-aminoethylamino) propyltrimethoxysilane modified ordered mesoporous silica micro-column and their determination by inductively coupled plasma optical emission spectrometry. J Hazard Mater 164(2-3): 1146-1151

Copat, C., Bella, F., Castaing, M., Fallico, R., Sciacca, S., Ferrante, M., 2012. Heavy metals concentrations in fish from Sicily (Mediterranean Sea) and evaluation of possible health risks to consumers. Bull. Environ. Contamin. Toxicol, 88(1), 78-83.

Das S, Unni B, Bhattacharjee M, Wann SB, Rao PG (2012) Toxicological effects of arsenic exposure in a freshwater teleost fish, Channa punctatus. African J Biotech 11(19):4447-4454

Datta S, Ghosh D, Saha DR, Bhattacharaya S, Mazumder S (2009) Chronic exposure to low concentration of arsenic is immunotoxic to fish: role of head kidney macrophages arsenic biomarkers of arsenic toxicity to Clarias batrachus. Aquat Toxicol 92(2):86-94

Delgado-Andrade, C., Navarro, M., Lopez, H., \& Lopez, M. C. (2003). Determination of total arsenic levels by hydride generation atomic absorption spectrometry in foods from south-east Spain: Estimation of daily dietary intake. Food Additives and Contaminants, 20(10), 923-932.

Duker AA, Carranza EJM, Hale M (2005) Arsenic geochemistry and health. Environ Int 31(5):631-641

Elçi L, Divrikli Ü, Soylak M (2008) Inorganic arsenic speciation in various water samples with GFAAS using coprecipitation. Int J Envir Anal Chem 88(10):711-723

Finkelman RB, OremW, Castranova V, Tatu CA, Belkin HE, Zheng B, et al. 2002; Health impacts of coal and coal use: possible solutions. Int J Coal Geol 50(1-4):425-43.

Gong, Z., Lu, X., Mingsheng, M., Corinn, W., Le, X.C., 2002. Arsenic speciation analysis. Talanta 58(1), 77-96.

Haque S., Johannesson, K. H. 2006 "Arsenic concentrations and speciation along a groundwater flow path: the Carrizo Sand aquifer, Texas,USA," Chemical Geology, vol. 228, no. 1-3,pp. 57-71.

Has-Schon, E., Bogut, I., \& Strelec, I. (2006). Heavy metal profile in five fish species included in human diet, domiciled in the end flow of River Neretva (Croatia). Archives of Environmental Contamination and Toxicology, 50(4), 545-551.

Hughes MF, Beck BD, Chen Y, Lewis AS, Thomas DJ (2011) Arsenic exposure and toxicology: a historical perspective. Toxicol Sci 123(2):305-332

Imran M, Kumar D, Kumar N, Qayyum A, Saeed A, Bhatti MS (2014) Environmental concerns of underground coal gasification. Renew Sust Energ Rev 31:600-610

J Ali, Kazi TG, Baig JA, Afridi HI, Arain MS, Brahman KD, Panhwar AH (2015): Arsenic in coal of the Thar coalfield, Pakistan, and its behavior during combustion. Environmental Science and Pollution Research, Environ Sci Pollut Res 22(11):8559-8566

Jankong, P., Chalhoub, C., Kienzl, N., Goessler, W., Francesconi, K., \& Visoottiviseth, P. (2007). Arsenic accumulation and speciation in freshwater fish living in arsenic contaminated waters. Environmental Chemistry, 4(1), 11-17. 
Kar S, Maity JP, Jean JS, Liu CC, Liu CW, Bundschuh J, Lu HY (2011) Health risks for human intake of aquacultural fish: arsenic bioaccumulation and contamination. J Env Sci Heal A 46(11):1266-1273.

Kazi, T. G., Brahman, K. D., Afridi, H. I., Arain, M. B., Talpur, F. N., Akhtar, A., 2016. The effects of arsenic contaminated drinking water of livestock on its total levels in milk samples of different cattle: risk assessment in children. Chemosphere, $165,427-433$.

Kazi, T.G., Arain, M.B., Jamali, M.K., Jalbani, N., Afridi, H.I., Sarfraz, R.A., Baig, J.A., Shah, A.Q., 2009. Assessment of water quality of polluted lake using multivariate statistical techniques: a case study. Ecotoxicology and Environmental Safety 72(2), 301-309.

Kumari B, Kumar V, Amit K. Sinha, Jawaid Ahsan,A. K. Ghosh, Hanping Wang, Gudrun DeBoeck (2017) Toxicology of arsenic in fish and aquatic systems. Environ Chem Lett 15(1), 43-64.

Liang P, Peng L, Yan P (2009) Speciation of As (III) and As (V) in water samples by dispersive liquid-liquid microextraction separation and determination by graphite furnace atomic absorption spectrometry. Microchim Acta 166(1-2):47-52.

Maity, S., Chakravarty, S., Thakur, P., Gupta, K.K., Bhattacharjee, S., Roy, B.C., 2004. Evaluation and standardisation of a simple HG-AAS method for rapid speciation of $\mathrm{As}(\mathrm{III})$ and $\mathrm{As}(\mathrm{V})$ in some contaminated groundwater samples of West Bengal, India. Chemosphere 54(8), 1199-1206.

Masscheleyn, P. H. Delaune, R. D. Patrick Jr. W.H. 1991 "Effect of redox potential and pH on arsenic speciation and solubility in a contaminated soil," Environmental Science and Technology, vol. 25, (8) 1414-1419.

Milton, A.H., Hasan, Z., Shahidullah, S.M., Sharmin, S., Jakariya, M.D., Rahman, M., Keithdear, Smith W., 2004. Association between nutritional status and arsenicosis due to chronic arsenic exposure in Bangladesh. International Journal of Environmental Health Research 14(2), 99-108.

Moiseenko T.I., L.P. Kudryavtseva, (2001) Trace metal accumulation and fish pathologies in areas affected by mining andmetallurgical enterprises in the Kola Region, Russian, Environ. Pollut. 114(2), 285-297

Morales, K.H., Ryan, L., Kuo, T.L., Wu, M.M., Chen, C.J., 2000. Risk of internal cancers from arsenic in drinking water. Environmental Health Perspectives 108(7), 655-661.

Murata, R., Shimizu, T., Uehara, N., 2005. Speciation of As(III) and as (V) in water. Bunseki Kagaku 54 (9), $831-836$.

Pedlar RM, Ptashynski MD, Evans R, Klaverkamp JF (2002b) Toxicological effects of dietary arsenic exposure in lake whitefish (Coregonus clupeaformis). Aquat Toxicol 57(3):167-189

Pedlar RM, Ptashynski MD, Wautier KG, Evans R, Baron CL, Klaverkamp JF (2002a) The accumulation, distribution and toxicological effects of dietary arsenic exposure in lake white (Coregonus clupeaformis) and lake trout (Salvelinus namaycush). Comp Biochem Physiol C 131(1):73-91.

Rafique, T., Naseem, S., Usmani, T. H., Bashir, E., Khan, F. A., \& Bhanger, M. I. (2009). Geochemical factors controlling the occurrence of high fluoride groundwater in the Nagar Parkar area, Sindh, Pakistan. Journal of Hazardous Material, 171(13), 424-430.

Rosemond, S. D., Xie, Q., \& Liber, K. (2008). Arsenic concentration and speciation in five freshwater fish species from Back Bay near Yellowknife, NT, Canada. Environmental Monitoring and Assessment, 147(1-3), 199-210. 
Shah, A. Q., Kazi, T. G., Arain, M. B., Baig, J. A., Afridi, H. I., Kandhro, G. A., Jamali, M. K., 2009. Hazardous impact of arsenic on tissues of same fish species collected from two ecosystem. J Hazard Mater, 167(1-3), 511-515.

Singh AK, Mahato M, Neogi B, Tewary B, Sinha A (2012) Environmental geochemistry and quality assessment of mine water of Jharia coalfield, India. Environ Earth Sci 65(1):49-65

Singh AK, MahatoMK, Neogi B, Singh K (2010) Quality assessment of mine water in the Raniganj coalfield area, India. Mine Water Environ 29(4):248-262

Singh, A.K., 2006. Chemistry of arsenic in groundwater of GangeseBrahmaputrariverbasin.Curr Sci. 91, 599-606.

Smedley, P.L., Nicolli, H.B., Macdonald, D.M.J., Barros, A.J., Tullio, J.O., 2002. Hydrogeochemistry of arsenic and other inorganic constituents in ground water from La Pampa, Argentina. Applied Geochemistry 17(3), 259-284.

Suhendrayatna, O. A., Nakajima, T., \& Maeda, S. (2001). Metabolism and organ distribution of arsenic in the freshwater fish Tilapia mossambica. Applied Organometallic Chemistry, 15, 566-571.

Swaine, D.J., 2000. Why trace elements are important. Fuel Process Technol;65-66:21-33.

Thirunavukkarasu, O.S., Viraraghavan, T., Subramanian, K.S., Tanjore, S., 2002. Organic arsenic removal from drinking water. Urban Water 4(4), 415-421.

Thornton, I., Farago, M. (1997). The geochemistry of arsenic. In Arsenic (pp. 1-16). Springer, Dordrecht.

Tisler T, Zagorc-Koncan J (2002) Acute and chronic toxicity of arsenic to some aquatic organisms. Bull Environ Contam Toxicol 69(3):421-429.

Tripathy, D., 2010Determination of trace elements concentration in mine water and trace elements index in some coal mines of jharia coalfield 29(3): 385-390

Vasquez, L. V., Hernandez, J. R., Lopez, J. R., Uribe, A. S., \& Mancilla, O. L. (2006). The origin of fluoride in groundwater supply to Hermosillo City, Sonora, Mexico. Environmental Geology, 51(1), 17-27.

Wang, S., \& Mulligan, C. N. (2006). Effect of natural organic matter on arsenic release from soils and sediments into groundwater. Environmental geochemistry and health, 28(3), 197-214.

Yoshida, T., Yamauchi, H., Sun, G.F., 2004. Chronic health effects in people exposed to arsenic via the drinking water: doseresponse relationships in review. Toxicology and Applied Pharmacology 198 (3), 243-252.

Zhang, L., Ishi, D., Shitou, K., Morita, Y., Isozaki, A., 2005. Simultaneous multielements analysis of total As, Se and Sb on TiO2 by slurry sampling graphite furnace atomic absorption spectroscopy. Talanta 68 (2), 336-342.

Zhang, L., Morita, Y., Yoshikawa, K., Isozaki, A., 2007. Direct simultaneous determination for ultratrace As, Se and Sb in river water with graphite-furnace atomic absorption spectrometry by TiO2-slurry sampling. Analytical Sciences 23 (3), 365369.

\section{Tables}

Table 1. Validation of the proposed method for determination of As in certified reference material of water and fish 


\begin{tabular}{|c|c|c|c|c|}
\hline SRM 1643e & Certified values & Measured values & \% Recovery ${ }^{a}$ & $\begin{array}{l}{ }^{b} \text { Paired t-test, } \\
{ }^{c} t_{\text {Experimental }}\end{array}$ \\
\hline $\mathrm{Fe}\left(\mathrm{mg} \mathrm{L}^{-1}\right)$ & $98.1 \pm 1.4$ & $97.0 \pm 2.51$ & 98.8 & 0.453 \\
\hline tAs $\left(\mu g L^{-1}\right)$ & $60.4 \pm 0.72$ & $59.4 \pm 1.88$ & 98.3 & 0.385 \\
\hline \multicolumn{5}{|c|}{ Certifed material of muscles of dog fish (DORM 2) } \\
\hline tAs $\left(\mu g^{-1}\right)$ & $18.0 \pm 1.1$ & 17.7 & 98.3 & 0.341 \\
\hline \multicolumn{5}{|c|}{ Standard addition of arsenic species in real water samples } \\
\hline Species & Added conc. $(\mu \mathrm{g} / \mathrm{L})$ & Mean \pm SD $(\mu \mathrm{g} / \mathrm{L})$ & $\%$ Recovery & \\
\hline \multirow[t]{3}{*}{$\mathrm{As}^{3+}$} & 0 & $17.8 \pm 3.15$ & - & \\
\hline & 5 & $\begin{array}{l}22.4 \pm 1.1 \\
(4.91)^{d}\end{array}$ & 98.2 & 0.338 \\
\hline & 10 & $\begin{array}{l}37.1 \pm 1.72 \\
(4.63)\end{array}$ & 98.1 & 0.285 \\
\hline \multirow[t]{3}{*}{ iAs } & 0 & $25.8 \pm 1.42$ & - & \\
\hline & 10 & $\begin{array}{l}35.2 \pm 2.22 \\
(6.3)\end{array}$ & 98.3 & 0.294 \\
\hline & 20 & $\begin{array}{l}45.2 \pm 3.05 \\
(6.74)\end{array}$ & 98.7 & 0.312 \\
\hline
\end{tabular}

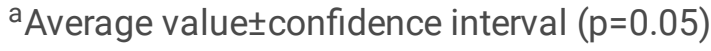

${ }^{\mathrm{b}}$ Percent recovery=

${ }^{c}$ Paired t-test between certified values/standards addition vs found values,

degree of freedom $(n=5)$

$t_{\text {Critical }}$ at $95 \%$ confidence limit $=2.57$

dValues in parenthesis indicate RSD

Table 2: Concentrations of physicochemical parameters and cation species in ground water of aquifer 2, drain outlet and four sites of reservoir 


\begin{tabular}{|c|c|c|c|c|c|c|c|}
\hline $\begin{array}{l}\text { Parameters } \\
\text { / }\end{array}$ & $\begin{array}{l}\text { WHO } \\
\text { Limits }\end{array}$ & Aquifer 2 & DW & RW1 & RW2 & RW3 & RW4 \\
\hline $\mathrm{pH}$ & $6.5-8.5$ & $8.3 \pm 0.13$ & $78 \pm 0.24$ & $7.55 \pm 0.24$ & $7.45 \pm 0.21$ & $7.3 \pm 0.18$ & $7.1 \pm 0.15$ \\
\hline $\begin{array}{l}\mathrm{EC} \\
\mathrm{mS} / \mathrm{cm}\end{array}$ & 0.25 & $10.2 \pm 1.5$ & $10.4 \pm 1.1$ & $9.2 \pm 1.6$ & $8.5 \pm 1.6$ & $7.5 \pm 1.16$ & $6.4 \pm 0.92$ \\
\hline aTDS & 1000 & $9300 \pm 220$ & $9100 \pm 250$ & $8300 \pm 295$ & $\begin{array}{l}7270 \pm \\
356\end{array}$ & $6100 \pm 33$ & $5130 \pm 312$ \\
\hline${ }^{\mathrm{a}} \mathrm{HCO}_{3}{ }^{-}$ & - & $450 \pm 23.2$ & $442.7 \pm 22$ & $395 \pm 55.4$ & $310 \pm 49.3$ & $274 \pm 41.2$ & $238 \pm 34.5$ \\
\hline $\mathrm{a}^{\mathrm{a}} \mathrm{-}^{-}$ & 1.5 & $41.0 \pm 8.4$ & $37.7 \pm 6.5$ & $33.8 \pm 5.62$ & $30.8 \pm 4.42$ & $25.8 \pm 4.1$ & $22.6 \pm 4.26$ \\
\hline${ }^{\mathrm{a}} \mathrm{Fe}$ & 0.2 & $1.25 \pm 0.4$ & $1.20 \pm 0.54$ & $1.0 \pm 0.05$ & $0.82 \pm 0.04$ & $0.62 \pm 0.05$ & $0.45 \pm 0.03$ \\
\hline${ }^{\mathrm{b}} \mathrm{As}$ & 10 & $47.3 \pm 7.6$ & $46.2 \pm 6.8$ & $41.0 \pm 5.8$ & $37.5 \pm 5.6$ & $33.8 \pm 5.4$ & $32.2 \pm 4.8$ \\
\hline $\mathrm{b}_{\mathrm{iAs}}$ & - & $45.2 \pm 4.1$ & $44.1 \pm 4.2$ & $40.4 \pm 4.34$ & $36.5 \pm 5.86$ & $33.2 \pm 4.15$ & $31.8 \pm 3.46$ \\
\hline${ }^{\mathrm{b}} \mathrm{As} \mathrm{V}^{\mathrm{V}}$ & - & $29.8 \pm 3.7$ & $29.5 \pm 3.02$ & $21.5 \pm 3.8$ & $14.3 \pm 2.56$ & $10.6 \pm 1.67$ & $7.75 \pm 2$ \\
\hline \multirow[t]{2}{*}{ bAs"II } & - & $14.5 \pm 3.3$ & $14.6 \pm 3.16$ & $19.8 \pm 2.45$ & $22.6 \pm 3.25$ & $23.8 \pm 3.15$ & \\
\hline & & & & & & & $24.5 \pm 3.68$ \\
\hline
\end{tabular}

Key $={ }^{\mathrm{a}} \mathrm{mg} / \mathrm{L} ;{ }^{\mathrm{b}} \mu \mathrm{g} / \mathrm{L}$

Table 3 Determination of arsenic in different tissues of 0 . mossambicus (wet basis) and estimated daily intake of As $(\mu \mathrm{g} / \mathrm{g})$ 


\begin{tabular}{|llll|}
\hline Fish tissues & $\begin{array}{l}\text { Mean } \pm S . D \\
\mu \mathrm{g} / \mathrm{g}\end{array}$ & ${ }^{\mathrm{a} B A F}$ & ${ }^{\mathrm{b}} \mathrm{EDI}$ \\
\cline { 1 - 3 } Muscles & $0.9 \pm 0.16$ & 28.6 & \multirow{2}{*}{$3.75 \pm 0.63$} \\
\cline { 1 - 3 } gills & $1.11 \pm 0.14$ & 34.9 & \\
\cline { 1 - 3 } liver & $1.47 \pm 0.29$ & 46.6 & \\
\cline { 1 - 3 } scales & $0.48 \pm 0.012$ & 15.2 & \\
\hline
\end{tabular}

Key: abioaccumulation factor

${ }^{\mathrm{b}}$ Estimated daily intake

\section{Supplementary Files}

This is a list of supplementary files associated with this preprint. Click to download.

- Graphicalabstract.tif 